\title{
Vitamin C modulates DNA damage induced by hydrogen peroxide in human colorectal adenocarcinoma cell lines (HT29) estimated by comet assay in vitro
}

Renata Kontek ${ }^{1}$, Bogdan Kontek², Krzysztof Grzegorczyk ${ }^{3}$

\begin{abstract}
1'Laboratory of Cytogenetics, Department of General Genetics, Molecular Biology and Plant Biotechnology, University of Lodz, Poland

2Department of General Biochemistry, University of Lodz, Poland

${ }^{3}$ Department of Endoscopy and One Day Gastroenterology, Wl. Bieganski Memorial

Regional Specialist Hospital, Lodz, Poland
\end{abstract}

Submitted: 28 May 2012

Accepted: 20 August 2012

Arch Med Sci 2013; 9, 6: 1006-1012

DOI: 10.5114/aoms.2013.39791

Copyright @ 2013 Termedia \& Banach

\begin{abstract}
Introduction: Cancer cells, compared to normal cells, are under increased oxidative stress associated with oncogenic transformation, alterations in metabolic activity, and increased generation of reactive oxygen species.

Material and methods: We investigated the ability of vitamin $C$ to reduce the damage induced by hydrogen peroxide, in human colorectal adenocarcinoma cells in vitro by the comet assay. Additionally, we measured the kinetics and efficacy of the repair of DNA damage after incubation with vitamin $\mathrm{C}$ in the presence of $\mathrm{H}_{2} \mathrm{O}_{2}$.

Results: The obtained results showed that $1 \mathrm{~h}$ pre-incubation with vitamin $\mathrm{C}$ and exposure to $\mathrm{H}_{2} \mathrm{O}_{2}$ for the last 10 min of incubation caused a statistically significant $(p<0.05)$ increase in DNA migration in comet tails in all experimental series. For the $10 \mu \mathrm{M}, 25 \mu \mathrm{M}, 50 \mu \mathrm{M}, 100 \mu \mathrm{M}$ vitamin C concentrations the levels of DNA damage were as follows: $18.6 \%, 21.1 \%, 25.3 \%$ and $27.2 \%$, respectively, as compared to the untreated cells (3.26\%). However, in comparison with $\mathrm{H}_{2} \mathrm{O}_{2}$ alone $(29.1 \%)$, we observed a statistically significant $(p<0.05)$ decrease of the genotoxic effect in $\mathrm{HT} 29$ cells induced by $\mathrm{H}_{2} \mathrm{O}_{2}$ for the two lowest of concentrations of vitamin C: $10 \mu \mathrm{M}$ and $25 \mu \mathrm{M}$. The HT29 cells were able to achieve effective repair of the damaged DNA within 60 and 120 min after incubation with the tested compounds. All the values obtained in the test were statistically significant $(p<0.05)$.

Conclusions: Vitamin C caused a weaker DNA damaging effect of hydrogen peroxide and positively influences the level of oxidative DNA damage in HT29 cells (decrease $\sim 30 \%$ ). We noted that DNA damage was effectively repaired during 120 min postincubation in the tested cells and that oxidative damage was the major type of damage.
\end{abstract}

Key words: vitamin C, oxidative DNA damage, HT29 cells, comet assay.

\section{Introduction}

The effect of ascorbic acid (vitamin C) on cancer treatment has a controversial history [1]. These studies concluded that ascorbic acid treatment brought enhanced quality and prolongation of life. Recently, emerging evidence indicates that ascorbic acid in cancer treatment deserves reevaluation anew [2, 3]. Vitamin C plays an important role in cells; it maintains proper oxidation-reduction potentially participating in neutralization of reactive

\author{
Corresponding author: \\ Dr. Bogdan Kontek \\ Department \\ of General Biochemistry \\ University of Lodz \\ 141/143 Pomorska St \\ 90-236 Lodz, Poland \\ Phone: +48426354336 \\ Fax: +48 426354484 \\ E-mail: \\ kontekb@biol.uni.lodz.pl
}


oxygen species (ROS) and reactive nitrogen species (RNS) formed in the course of cellular metabolism or oncogenic transformation [4]. It was shown that ascorbic acid took part in the activation of genes involved in DNA repair, modulating the level of DNA damage in cells exposed to ROS in vivo and in vitro $[5,6]$. The observations suggested that supplementation of vitamin $C$ decreased the endogenous level of oxidative damage (oxidized pyrimidines and strand breaks) in lymphocyte DNA and might help to prevent diseases resulting from tissue damage caused by free radicals [7]. Although numerous studies describe protective action of vitamin C in ROS exposed cells, reports mentioning genotoxic and prooxidative action of ascorbate cannot be disregarded [8]. In vitro experiments with cell lines indicate that vitamin $C$ at low concentrations and additionally in the presence of transition metal ions acts as a prooxidant and increases the amount of damage to genetic material [9]. In that case the compound enters the Fenton reaction and contributes to the increased amount of damage through the induction of ROS. Mixtures of copper and iron ions with ascorbate cause DNA, lipid and protein damage in vitro, stimulating the formation of hydroxyl radical $\cdot \mathrm{OH}[10,11]$.

In the present study we determined the level of basal DNA damage and the efficacy of DNA repair, recognized in the alkaline comet assay after treatment with vitamin $\mathrm{C}$ with or without the presence of $10 \mu \mathrm{M} \mathrm{H}_{2} \mathrm{O}_{2}$ during the last 10 min of incubation at $4^{\circ} \mathrm{C}$ in $\mathrm{HT} 29$ cells in vitro. The percentage tail DNA (\% tail DNA) was evaluated in comparison with untreated cells and cells exposed to $\mathrm{H}_{2} \mathrm{O}_{2}$. To evaluate oxidatively modified DNA bases, we applied a repair enzyme: formamidopyrimidine-DNA glycosylase (Fpg).

\section{Material and methods}

Vitamin C, penicillin-streptomycin, MEM (nonessential amino acid solution), PBS (buffered saline), DAPI (4,6-diamidino-2-phenylindole), bovine serum albumin (BSA), $\mathrm{H}_{2} \mathrm{O}_{2}$ (hydrogen peroxide), and low melting point (LMP) and normal melting point (NMP) agaroses were obtained from Sigma Chemical Co. Fetal bovine serum (FBS), RPMI 1640 medium, and trypsin-EDTA were supplied by Cytogen (Poland). Fpg enzyme was purchased from the Institute of Biochemistry and Biophysics, Polish Academy of Sciences, Warsaw, Poland. All other chemicals were of the highest commercial grade available.

The human colorectal adenocarcinoma cell line (HT29) obtained from the American Type Culture Collection (ATCC) was cultured in RPMI 1640 medium supplemented with $10 \%$ inactivated FBS, $1 \%$ penicillin and streptomycin and 1\% MEM non-essential amino acid solution. Cultures of $0.5-1.0 \times 10^{6}$ cells $/ \mathrm{ml}$ were used for all the experiments. Cells were grown at $37^{\circ} \mathrm{C}, 5 \% \mathrm{CO}_{2}$ under standard conditions.

\section{Cell treatment}

Vitamin C taken from stock (20 mM) was added to the suspension of HT29 cells to give final concentrations of $10 \mu \mathrm{M}, 25 \mu \mathrm{M}, 50 \mu \mathrm{M}$ and $100 \mu \mathrm{M}$ and the cells were incubated with vitamin $\mathrm{C}$ for $1 \mathrm{~h}$ at $37^{\circ} \mathrm{C}$. For the last $10 \mathrm{~min}$ of incubation with vitamin C, part of HT29 cells were treated with $10 \mu \mathrm{M}$ $\mathrm{H}_{2} \mathrm{O}_{2}$ at $4^{\circ} \mathrm{C}$. Each experiment included a positive control, which was only $10 \mu \mathrm{M} \mathrm{H}_{2} \mathrm{O}_{2}$ applied for $10 \mathrm{~min}$ at $4^{\circ} \mathrm{C}$.

\section{Cell viability}

Cell viability was determined by trypan blue exclusion assay. After incubation of HT29 cells with described compounds, an equal volume of $0.4 \%$ of the trypan blue reagent was added to the cells and the percentage of viable cells was evaluated using a brightfield microscope (NIKON SE). For a single event, 100 cells were analyzed in three independent experiments.

\section{Comet assay}

The comet assay has gained wide acceptance as a valuable tool in fundamental DNA damage and repair studies [12], genotoxicity testing, and human biomonitoring $[13,14]$. Single cell gel electrophoresis (comet assay) is a very sensitive and rapid method for detection of alkali labile sites (ALS), single and double DNA strand breaks and crosslinks induced by genotoxic agents [15]. The comet assay was performed under alkaline conditions $(\mathrm{pH}$ $>13$ ) according to the procedure of Singh et al. [16]. Following $24 \mathrm{~h}$ incubation at $37^{\circ} \mathrm{C}$, the cancer cells were resuspended in $0.75 \%$ low melting point (LMP) agarose in PBS ( $\mathrm{pH} 7.4)$, and placed on microscope slides precoated with $0.5 \%$ normal melting point (NMP) agarose. To prevent additional DNA damage, all the steps were conducted under reduced light or in the dark. Cells were lysed for $1 \mathrm{~h}$ at $4^{\circ} \mathrm{C}$ in a buffer containing $2.5 \mathrm{M} \mathrm{NaCl}$, 100 mM EDTA, 1\% Triton X-100, 10 mM Tris- $\mathrm{HCl}, 1 \%$ $\mathrm{N}$-lauroylsarcosine sodium, $\mathrm{pH} 10$. Slides were placed in an electrophoresis unit for 40 min to allow DNA to relax in the electrophoretic solution consisting of $300 \mathrm{mM} \mathrm{NaOH}, 1 \mathrm{mM}$ EDTA, $\mathrm{pH}>13$, at $4^{\circ} \mathrm{C}$. Then the slides were subjected to electrophoresis $\left(4^{\circ} \mathrm{C}\right)$ for $23 \mathrm{~min}$ at an electric field strength of $0.86 \mathrm{~V} / \mathrm{cm}$, $25 \mathrm{~V}, 300 \mathrm{~mA}$. After electrophoresis the slides were neutralized in $0.4 \mathrm{M}$ Tris- $\mathrm{HCl}(\mathrm{pH} 7.5)$. DNA was stained with DAPI at a concentration of $2 \mu \mathrm{g} / \mathrm{ml}$. Slides were analyzed using a fluorescence microscope (Olympus BX 60F5, Olympus Optical Co. Ltd.) equipped with a UV-1 filter block at $360 \mathrm{~nm}$ connected to the computer-based image analysis system CASP - Comet Assay Software Project by Końca et al. [17]. 100 images were randomly selected from each sample, and the percentage of DNA in 


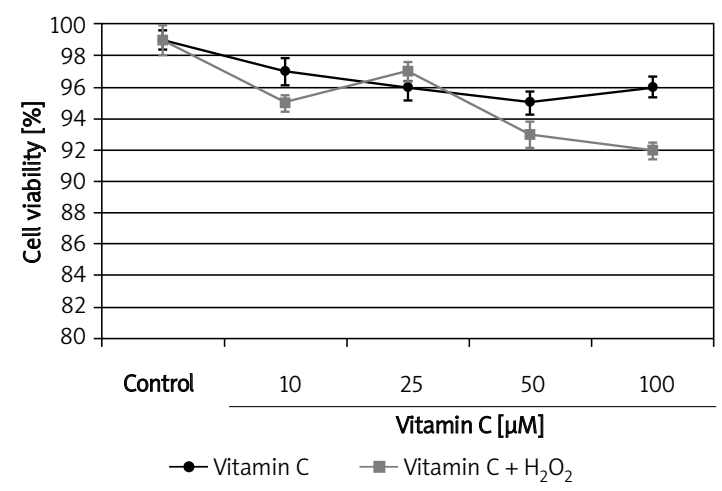

Figure 1. Effect of $1 \mathrm{~h}$ incubation with vitamin $\mathrm{C}$ on $\mathrm{HT} 29$ cell viability in the absence (black symbols) or in the presence (grey symbols) of $10 \mu \mathrm{M} \mathrm{H}_{2} \mathrm{O}_{2}$ for the last $10 \mathrm{~min}$ of incubation at $4^{\circ} \mathrm{C}$ measured by trypan blue exclusion method

Error bars denote S.E.M.; control - untreated cells

the comet tail (\% tail DNA) was measured. The \% tail DNA was positively correlated with level of DNA breakage and/or alkali labile sites in the cell and it was negatively correlated with the level of DNA crosslinks [18].

\section{DNA repair}

The HT29 cells were incubated with the tested compounds in described systems, and then washed and resuspended in a drug-free growth medium for $60 \mathrm{~min}$ and $120 \mathrm{~min}$ at $37^{\circ} \mathrm{C}$. The comet assay was performed as described above. The repair postincubation (recovery time) was optimized for testing of repair of DNA strand breaks [19].

\section{DNA repair enzyme treatment}

After the incubation with tested compounds and lysis, slides were washed three times $\left(5 \mathrm{~min}, 4^{\circ} \mathrm{C}\right)$

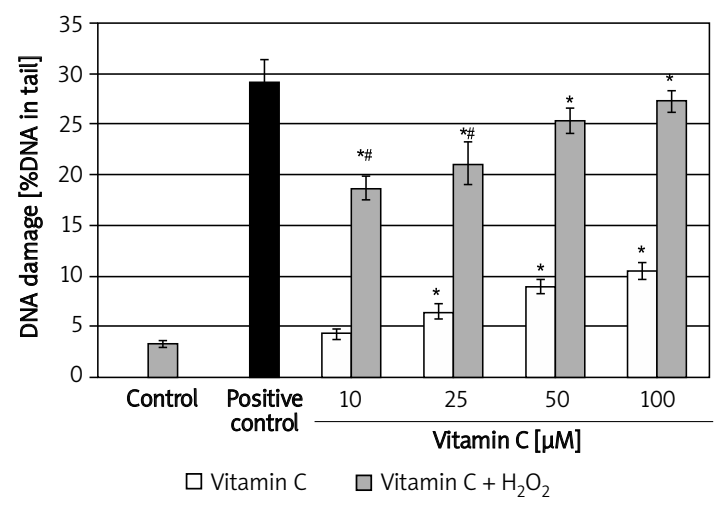

Figure 2. Mean percentage of DNA in the comet tails of HT29 cells exposed to vitamin C for $1 \mathrm{~h}$ at $37^{\circ} \mathrm{C}$ (white bars) as compared with incubation with vitamin $\mathrm{C}$ in the presence of $10 \mu \mathrm{M} \mathrm{H}_{2} \mathrm{O}_{2}$ for the last 10 min of exposure (grey bars). The number of cells scored in each individual was 100 and the analysis was repeated three times

Error bars denote S.E.M., negative control - untreated cells, positive control - $10 \mu \mathrm{M} \mathrm{H}_{2} \mathrm{O}_{2}$ (black bar), ${ }^{*} p<0.05$ as com pared with control, $\# p<0.05$ as compared with $10 \mu \mathrm{M} \mathrm{H}_{2} \mathrm{O}_{2}$ in Fpg buffer (40 mM HEPES-KOH, 0.1 M KCl, $0.5 \mathrm{mM}$ EDTA, $0.2 \mathrm{mg} / \mathrm{ml} \mathrm{BSA}, \mathrm{pH} 8.0$ ) and drained and the agarose was covered with $30 \mu \mathrm{l}$ of Fpg at $1 \mu \mathrm{g} / \mathrm{ml}$ in the buffer, sealed with a cover glass and incubated for $30 \mathrm{~min}$ at $37^{\circ} \mathrm{C}$. Further steps were as described above. Fpg is involved in the first step of the base excision repair to remove specific modified bases from DNA and create an apurinic and apyrimidinic site (AP-site), which is subsequently cleaved by its AP lyase activity giving a gap in the DNA strand. The gap can be detected by the comet assay. The enzyme excises mainly 2,6-diamino-4hydroxy-5-N-methyl formamidopyrimidine and 7,8-dihydro-8-oxo-2'deoxyguanine (8-oxo-G) [20]. Hydrogen peroxide was used as an oxidizing agent, which caused DNA damage recognized by Fpg.

\section{Statistical analysis}

The values in this study were presented as means \pm SEM. from three independent experiments. The differences between the experimental samples and control distribution were evaluated by Student's t-test $(p<0.05)$.

\section{Results}

\section{Cell viability}

The viability of HT29 cells before incubation was $99 \pm 0.41 \%$ (data not shown). The results of trypan blue staining of HT29 cells after $1 \mathrm{~h}$ incubation with different concentrations of the tested compounds are shown in Figure 1. We observed that both vita$\min \mathrm{C}$ and vitamin $\mathrm{C}$ in the presence of $10 \mu \mathrm{M} \mathrm{H}_{2} \mathrm{O}_{2}$ for the last 10 min of incubation caused a slight decrease in the viability of HT29 cells. Vitamin C at the maximal used concentration of $100 \mu \mathrm{M}$ caused a decrease of HT29 cell viability to $96 \pm 0.67 \%$ whereas vitamin $\mathrm{C}(100 \mu \mathrm{M})$ in the presence of $10 \mu \mathrm{M} \mathrm{H}_{2} \mathrm{O}_{2}$ for the last 10 min of incubation caused a decrease to $92 \pm 0.52 \%$. After 10 min incubation of $\mathrm{HT} 29$ cells with $10 \mu \mathrm{M} \mathrm{H} \mathrm{H}_{2}$ alone, we observed a decrease in the viability of the cells to $85 \pm 0.42 \%$.

\section{DNA damage}

The mean amounts of DNA in comet tails for HT29 cells exposed to vitamin $\mathrm{C}$ for $1 \mathrm{~h}$ in the absence and in the presence of $10 \mu \mathrm{M} \mathrm{H}_{2} \mathrm{O}_{2}$ are presented in Figure 2. After incubation of HT29 cells with $10 \mu \mathrm{M}$ vitamin $\mathrm{C}$ no statistically significant increase in DNA in comet tails (4.25 $\pm 0.54 \%)$ was observed. At the concentration of $25 \mu \mathrm{M}$ and $50 \mu \mathrm{M}$ statistically significant increases in DNA migration in comet tails were observed, by $6.48 \pm 0.73 \%$ and $8.94 \pm 0.69 \%$, respectively, as compared to the negative control (3.26 $\pm 0.41 \%)$. The highest DNA damage, with an increase of $10.52 \pm 0.9 \%$ in comet tails, was noted after the exposure of HT29 cells to vita- 
min $C$ at the concentration of $100 \mu \mathrm{M}$. The increase in the level of DNA damage during incubation with vitamin $\mathrm{C}$ alone was correlated with the increase of the vitamin $\mathrm{C}$ concentrations. After the treatment with vitamin $\mathrm{C}$ in the presence of $10 \mu \mathrm{M} \mathrm{H}_{2} \mathrm{O}_{2}$ during the last 10 min of incubation, a statistically significant (as compared with untreated cells) increase in DNA migration in the comet tails with increasing vitamin $C$ concentrations was noted. For the $10 \mu \mathrm{M}$, $25 \mu \mathrm{M}, 50 \mu \mathrm{M}$, and $100 \mu \mathrm{M}$ vitamin C concentrations the levels of DNA damage were as follows: $18.6 \pm 1.34 \%, 21.1 \pm 2.1 \%, 25.3 \pm 2.04 \%$ and 27.2 $\pm 2.6 \%$, respectively. However, compared with the positive control $\left(10 \mu \mathrm{M} \mathrm{H}_{2} \mathrm{O}_{2}\right.$ alone), we observed that $1 \mathrm{~h}$ pre-incubation of cells with vitamin $\mathrm{C}$ and exposure to $\mathrm{H}_{2} \mathrm{O}_{2}$ caused a decrease of the genotoxic effect in $\mathrm{HT} 29$ cells induced by $10 \mu \mathrm{M} \mathrm{H}_{2} \mathrm{O}_{2}$, which evoked strong migration of DNA in comet tails $(29.1 \pm 2.54 \%)$ (Figure 2). We noted that in HT29 cells after incubation with the two highest con- centrations of vitamin $\mathrm{C}$ before exposure of $\mathrm{H}_{2} \mathrm{O}_{2}$, there were no statistically significant differences compared with the positive control. Typical fluorescence microscope images (comet) of the $\mathrm{HT}_{2} 9$ cells exposed to vitamin $\mathrm{C}$ in the presence of $\mathrm{H}_{2} \mathrm{O}_{2}$ are shown in Figure 3.

\section{DNA repair}

We also analyzed kinetics of DNA damage in HT29 cells exposed for $1 \mathrm{~h}$ at $37^{\circ} \mathrm{C}$ to vitamin $\mathrm{C}$ in the presence of $10 \mu \mathrm{M} \mathrm{H}_{2} \mathrm{O}_{2}$ for the last 10 min of incubation at $4^{\circ} \mathrm{C}$ after $60 \mathrm{~min}$ and $120 \mathrm{~min}$ postincubation in medium free of test compounds (Figure 4). The comet tail DNA of the untreated cells was constant, indicating that preparation and subsequent processing of the HT29 cells did not introduce significant damage to their DNA. The HT29 cells exposed to vitamin $\mathrm{C}$ with $10 \mu \mathrm{M} \mathrm{H}_{2} \mathrm{O}_{2}$ were able to remove damage to their DNA within 60 min, but it was still
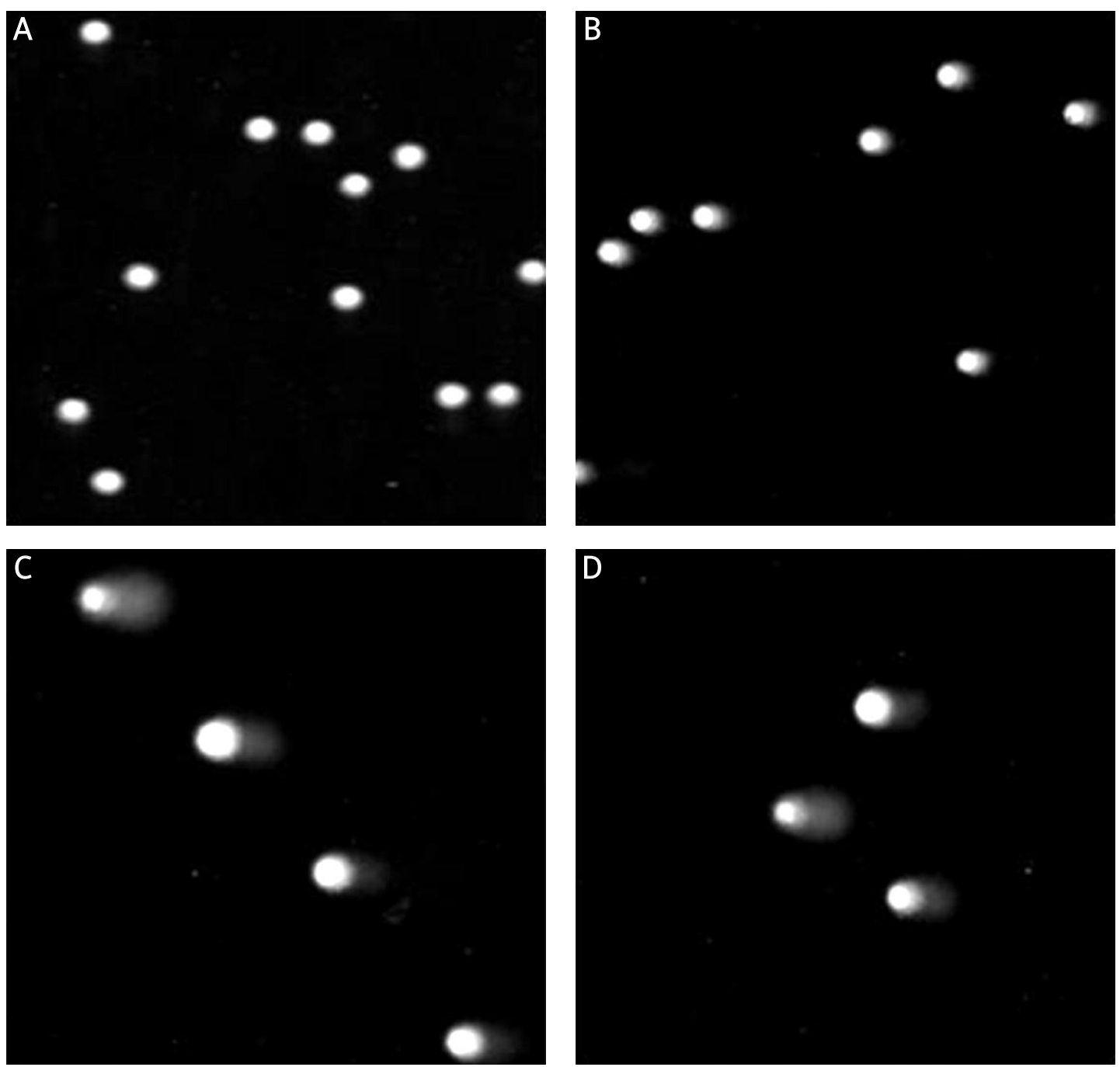

Figure 3. Fluorescence images of comets exposed to vitamin $C$ at the concentration of $25 \mu \mathrm{M}(\mathrm{B}), 50 \mu \mathrm{M}(\mathrm{C})$ and 100 $\mu \mathrm{M}$ (D) for $1 \mathrm{~h}$ at $37^{\circ} \mathrm{C}$ in the presence of $10 \mu \mathrm{M} \mathrm{H}_{2} \mathrm{O}_{2}$ for the last 10 min of exposure in HT29 cells (B-D) as compared to untreated cells (A) 


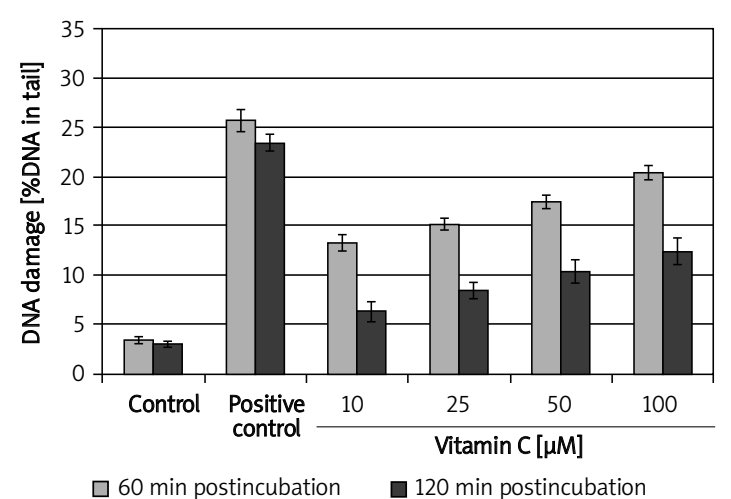

Figure 4. Efficacy of the repair of DNA damage in HT2 cells exposed for $1 \mathrm{~h}$ at $37^{\circ} \mathrm{C}$ to vitamin $\mathrm{C}$ in the presence of $10 \mu \mathrm{M} \mathrm{H}_{2} \mathrm{O}_{2}$ for the last 10 min of incubation at $4^{\circ} \mathrm{C}$ after $60 \mathrm{~min}$ and 120 min postincubation in medium free of test compounds. The number of cells scored in each individual was 100 , and the analysis was repeated three times

Error bars denote S.E.M., control - untreated cells, positive control - $10 \mathrm{MM} \mathrm{H}_{2} \mathrm{O}_{2}$

high. The amount of DNA in the comet tails after 60 min of postincubation can be explained by the accumulation of a large number of DNA strand breaks which were not visible directly after the incubation. Effective DNA repair through excision can lead to the formation of secondary DNA strand breaks, visualization of which in the comet test consists in the increase of DNA migration in the tail [17]. During the next hour of incubation (60-120 min) the values decreased to $6.29 \pm 1.03 \%$ for the lowest of the applied concentrations $(10 \mu \mathrm{M}), 8.47 \pm 0.82 \%$ for the concentration of $25 \mu \mathrm{M}, 11.34 \pm 1.2 \%$ for the concentration of $50 \mu \mathrm{M}$, and $15.38 \pm 1.32 \%$ for the highest of the applied concentrations $(100 \mu \mathrm{M})$. As compared to the levels of DNA damage following $60 \mathrm{~min}$ of postincubation, significant decrease in DNA migration in the comet tails of HT29 cells was noted after 120 min of postincubation. It was demonstrated that DNA damage was effectively repaired during $120 \mathrm{~min}$ postincubation in the tested cells.

Figure 5 presents the values of the percentage of DNA in the comet tails in HT29 cells after $1 \mathrm{~h}$ exposure to all the tested concentrations of vitamin $\mathrm{C}$ and vitamin $\mathrm{C}$ in the presence of $\mathrm{H}_{2} \mathrm{O}_{2}$ for the last 10 min of incubation at $4^{\circ} \mathrm{C}$. To allow comparison of the obtained results, a part of HT29 cells was incubated with the tested compounds, but in the absence of Fpg enzyme. The cells exposed to 10$100 \mu \mathrm{M}$ vitamin $\mathrm{C}$ in the presence of $10 \mu \mathrm{M} \mathrm{H}_{2} \mathrm{O}_{2}$ and treated with Fpg enzyme showed a higher level of DNA migration in the comet tails as compared to the results obtained for the cells that were not treated with Fpg enzyme. The level of DNA damage (\%) increased with increasing concentration of vitamin $C$ in individual trials. The obtained results suggest that oxidative damage was the predominant type of damage among the observed ones.

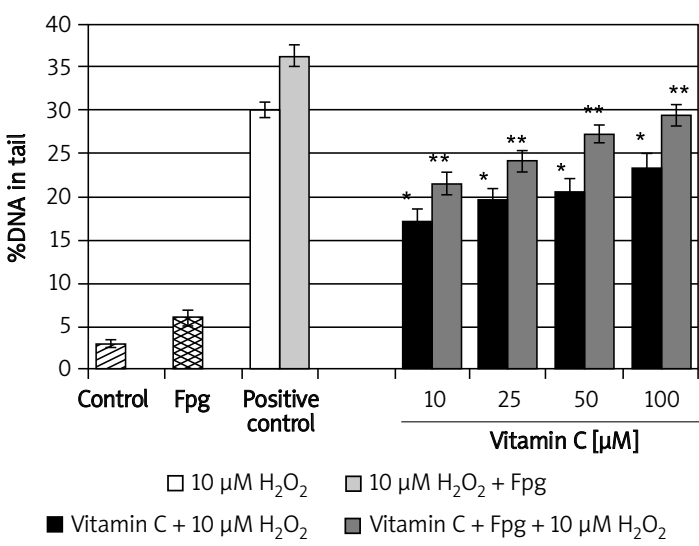

Figure 5. Percentage of DNA in the comet tails of HT2 2 cells exposed for $1 \mathrm{~h}$ at $37^{\circ} \mathrm{C}$ to vitamin $\mathrm{C}$ in the presence of $10 \mu \mathrm{M} \mathrm{H}_{2} \mathrm{O}_{2}$ for the last $10 \mathrm{~min}$ of incubation at $4^{\circ} \mathrm{C}$ and Fpg enzyme at $1 \mu \mathrm{g} / \mathrm{ml}$ (dark grey bars) as compared with HT29 cells treated with vitamin $C$ in the absence of Fpg (black bars). The number of cells scored in each individual was 100 , and the analysis was repeated three times

Error bars denote S.E.M., control - untreated cells, positive control: $10 \mu \mathrm{M} \mathrm{H}_{2} \mathrm{O}_{2}$ (light grey bar) and $10 \mu \mathrm{M} \mathrm{H}_{2} \mathrm{O}_{2}+\mathrm{Fpg}$ (white bar), ${ }^{*} p<0.05$ as compared with $10 \mu \mathrm{M} \mathrm{H}_{2} \mathrm{O}_{2},{ }^{\star *} p<0.05$ as compared with $10 \mu \mathrm{M} \mathrm{H}_{2} \mathrm{O}_{2}+\mathrm{Fpg}$

\section{Discussion}

Colorectal cancer is a disease having the second highest mortality rate among cancers in developed countries, including Poland. According to the World Health Organization, there are 945,000 newly diagnosed cases each year, 492,000 of which are fatal [21]. The incidence of colorectal cancer is similar for men and women; however, the prevalence of this disease remains higher in men than in women $35 \%$ lower in women) [22]. In the present paper we used a human colorectal adenocarcinoma cell line to demonstrate the effect that vitamin $\mathrm{C}$ may exert at the level of DNA damage on cancer cells in the presence of hydrogen peroxide. The favorable influence of vitamin $C$ on the human organism has long been known, but its effects on tumor cells and in tumor treatment are controversial. Vitamin $\mathrm{C}$ is one of the aqueous-phase antioxidants inhibiting induction of free-radical chain reactions [23]. Interactions of free radicals with DNA can lead to the formation of single-strand or double-strand breaks, formation of AP sites and DNA-protein and DNA-DNA crosslinks, and various chemical modifications of nitric bases. Numerous studies have been concentrated on modulating the influence of antioxidative vitamins, including vitamin C, on the level of DNA damage in cells in vitro and in vivo, induced by factors triggering free-radical reactions [24].

Experiments in this study indicated that $1 \mathrm{~h}$ preincubation with vitamin $\mathrm{C}$ in the presence of $10 \mu \mathrm{M}$ $\mathrm{H}_{2} \mathrm{O}_{2}$ for the last 10 min of exposure induced DNA damage in HT29 cells and was correlated with the increase of vitamin C concentrations. However, 
compared with the positive control, after exposure of $\mathrm{HT} 29$ cells to vitamin $\mathrm{C}$ in the presence of $\mathrm{H}_{2} \mathrm{O}_{2}$, we observed a decreased level of DNA damage in $\mathrm{HT} 29$ cells induced by $\mathrm{H}_{2} \mathrm{O}_{2}$. Furthermore, increasing concentrations of vitamin $\mathrm{C}$ resulted in increased levels of DNA damage in the comet tails. This fact can be explained by the involvement of high concentrations of vitamin $C$ in the induction of cell death in which DNA breaks were generated. In addition, vitamin C may involved in the Fenton reaction leading to the generation of $\mathrm{OH}$ radicals, responsible for DNA oxidative damage in the in vitro system [25]. In cancer cells the level of copper ions increases, which can have a toxic influence on the tested cells. It should be noted that the prooxidative activity of ascorbate is revealed only in the presence of transition metal ions, and it is a matter of doubt if there are conditions for revealing the pro-oxidative activity in vivo, for iron and copper ions are characterized by limited availability to living organism tissues. Ions of those metals are bound by proteins present in cells: ferritin, transferrin and ceruloplasmin [26]. Pro-oxidative activity of low concentrations of vitamin $C$ in vitro is associated not only with its involvement in the Fenton reaction, but also in reactions with lipid peroxides. It was shown that vitamin $\mathrm{C}$ induces decomposition of lipid hydroperoxides into compounds forming stable adducts with DNA [27]. Also of importance in relation to the purported pro-oxidative activity of vitamin $C$ is that vitamin $C$ has been reported to induce cell death, nuclear fragmentation and internucleosomal DNA cleavage in human myelogenous leukemia cell lines, all in line with the ability of high concentrations of vitamin C to induce apoptosis in various tumor cell lines [28, 29]. Bhat et al. [9] observed in their experiments that, at concentrations of $100-200 \mu \mathrm{M}$, ascorbic acid is able to generate significant lymphocyte DNA degradation. Although the mechanism of ascorbic acid toxicity is not firmly established, there are results indicating the stimulatory effects on apoptotic pathways, accelerated pro-oxidative damage that cannot be repaired by tumor cells, and increased oxidation of ascorbic acid (at high concentrations in plasma) to a toxic metabolite [30]. Takemura et al. [31] observed that a high dose of ascorbic acid induced cell death of four human mesothelioma cell lines. Ascorbic acid mediated cell death was at least due to ROS, especially hydrogen peroxide, accompanied by the disruption of mitochondria structure. Błasiak et al. [32] reported that $10 \mu \mathrm{M}$ vitamin $\mathrm{C}$ in the presence of idarubicin (0.001 to $10 \mu \mathrm{M}$ ) (anthracycline anticancer drug) decreased the level of DNA damage in normal lymphocytes in vitro. In tumor cells, the presence of vitamin $C$ increased the percentage of DNA in the comet tails - thus it can be considered as a compound increasing the activity of idarubicin in chemotherapy. In another study, the same author [33], studying the influence of vitamin $\mathrm{C}$ and of quercetin on damage induced by N-methyl-N'-nitro-N-nitrosoguanidine (MNNG) in human lymphocytes in vitro, found that the presence of $50 \mu \mathrm{M}$ vitamin $\mathrm{C}$ inhibits the damaging effect of MNNG, but at high concentrations $(250 \mu \mathrm{M})$ vitamin $C$ had a pro-oxidative effect, increasing the level of damage in the cells exposed to MNNG. Similar results were reported by Woźniak et al. [34], studying cisplatin activity in the presence of vitamin $C(50 \mu \mathrm{M})$ in lymphocytes and human chronic myelogenous leukemia cells (K562) in vitro. In both cell types the vitamin caused an increase in DNA damage over the level observed in the negative control. The target data suggest dual nature of vitamin C activity: antioxidative and pro-oxidative, both for normal cells and cells of neoplastic lines in vitro. This is also confirmed by the results obtained in this study. Reports on malignant cancer morbidity among people taking vitamin preparations containing vitamin $\mathrm{C}$ are still ambiguous. It was observed that application of vitamin $C$ in various doses not reduce incidents of all types of oxidative DNA damage in human lymphocytes [26].

The results obtained in this study on HT29 cells in vitro indicate that vitamin $C$ positively influences the level of oxidative DNA damage in cancer cells. We observed that vitamin $\mathrm{C}$ in the presence of $10 \mu \mathrm{M} \mathrm{H}_{2} \mathrm{O}_{2}$ caused a slight decrease in the viability of HT29 cells. The presence of vitamin C in tested samples caused a weaker DNA damaging effect of hydrogen peroxide. The cells exposed to tested compounds were able to carry out effective repair of the damaged DNA within 120 min after the end of incubation. The HT29 cells incubated with Fpg enzyme recognizing oxidative DNA damage showed higher level of DNA damage, as compared to the control cells. As expected, the damage was mainly of oxidative nature. The obtained results allow us to conclude that patients suffering from colorectal cancer must have appropriate doses of vitamin C prescribed. Antioxidants have a protective effect for normal tissues by counteracting the unfavorable activity of toxic substances and metabolites present in the human organism and they constitute a part of the antioxidant barrier.

\section{References}

1. Levine M, Espey MG, Chen Q. Losing and finding a way at $C$ : new promise for pharmacologic ascorbate in cancer treatment. Free Radic Biol Med 2009; 47: 27-9.

2. Chen Q, Espey MG, Krishna MC, et al. Pharmacologic ascorbic acid concentrations selectively kill cancer cells: action as a pro-drug to deliver hydrogen peroxide to tissues. Proc Natl Acad Sci USA 2005; 102: 13604-9.

3. Padayatty SJ, Sun H, Wang Y, et al. Vitamin C pharmacokinetics: implications for oral and intravenous use. Ann Intern Med 2004; 140: 533-7. 
4. Behrend L, Henderson G, Zwacka RM. Reactive oxygen species in oncogenic transformation. Biochem Soc Trans 2003; 31: 1441-4.

5. Valko M, Rhodes CJ, Moncol J, Izakovic M, Mazur M. Free redicals, metals and antioxidants in oxidative stressinduced cancer. Chem Biol Interact 2006; 160: 1-40.

6. Arrigoni O, De Tullio MC. Ascorbic acid: much more than just an antioxidant (review). Biochim Biophys Acta 2002; 1569: 1-9.

7. Lee KW, Lee HJ, Surh YJ, Lee CY. Vitamin C and cancer chemoprevention. Am J Clin Nutr 2003; 78: 1074-8.

8. Drisko JA, Chapman J, Hunter VJ. The use of antioxidant therapies during chemotherapy. Gynecol Oncol 2003; 88: 434-9.

9. Bhat SH, Azmi AS, Hanif S, Hadi SM. Ascorbic acid mobilizes endogenous copper in human peripheral lymphocytes leading to oxidative DNA breakage: a putative mechanism for anticancer properties. Int J Biochem Cell Biol 2006; 38: 2074-81.

10. Chakraborty H, Ray SN, Chakraborty S. Lipid peroxidation associated protein damage in rat brain crude synaptosomal fraction mediated by iron and ascorbate. Neurochem Int 2001; 39: 311-7.

11. Fenech M, Ferguson LR. Vitamins/minerals and genomic stability in humans. Mutat Res 2001; 475: 1-6.

12. Speit G, Hartmann A. The comet assay: a sensitive genotoxicity test for the detection of DNA damage. Methods Mol Biol 2005; 291: 85-95.

13. Möller P. The alkaline comet assay: towards validation in biomonitoring of DNA damaging exposures. Basic Clin Pharmacol Toxicol 2006; 98: 336-45.

14. Dhawan A, Bajpayee M, Parmar D. Comet assay: a reliable tool for the assessment of DNA damage in different models. Cell Biol Toxicol 2009; 25: 5-32.

15. Liao W, McNutt MA, Zhu WG. The comet assay: a sensitive method for detecting DNA damage in individual cells. Methods 2009; 48: 46-53.

16. Singh NP, McCoy T, Tice RR, Schneider EL. A simple technique for quantitation of low levels of DNA damage in individual cells. Exp Cell Res 1988; 175: 184-92.

17. Końca KA, Lankoff A, Banasik A, et al. A cross-platform public domain PC image-analysis program for the comet assay. Mutat Res 2003; 534: 15-20.

18. Tice RR, Agurell E, Anderson D, et al. Single gel/comet assay: guidelines for in vitro and in vivo genetic toxicology testing. Environ Mol Mutagen 2000; 35: 206-21.

19. Matlawska-Wasowska K, Rainczuk K, Kalinowska-Lis U, Osiecka R, Ochocki J. Genotoxicity of novel trans-platinum(II) complex with diethyl (pyridin-4-ylmethyl) phosphate in human non-small cell lung cancer cells A549. Chem Biol Interact 2007; 168: 135-42.

20. Speit G, Schütz P, Bonzheim I, Trenz K, Hoffman H. Sensitivity of the FPG protein towards alkylation damage in the comet assay. Toxicol Letters 2004; 146: 151-8.

21. Smolińska K, Paluszkiewicz P. Risk of colorectal cancer in relation to frequency and total amount of red meat consumption. Systematic review and meta-analysis. Arch Med Sci 2010; 6: 605-10.

22. Klimczak A, Kempińska-Mirosławska B, Mik M, Dziki Ł, Dziki A. Incidence of colorectal cancer in Poland in 19992008. Arch Med Sci 2011; 7: 673-8

23. Agil A, Fraile R, Acuna-Castroviejo D. Changes in plasma susceptibility to lipid peroxidation and vitamin $C$ in preterm and full-term neonates. Arch Med Sci 2008; 3: 324-8.

24. Williams GM, Jeffrey AM. Oxidative DNA damage: endogenous and chemically induced. Regul Toxicol Pharmacol 2000; 32: 283-92.
25. Rietjens IM, Boersma MG, de Haan L, et al. The prooxidant chemistry of the natural antioxidants vitamin $C$ vitamin E, carotenoids and flavonoids. Environ Toxicol Pharmacol 2002; 11: 321-33.

26. Konopacka M. Role of vitamin C in oxidative DNA damage [Polish]. Postepy Hig Med Dosw 2004; 58: 343-8.

27. Lee $\mathrm{SH}$, Oe T, Blair I A. Vitamin C-induced decomposition of lipid hydroperoxides to endogenous genotoxins. Science 2001; 292: 208.

28. Sakagami H, Satoh K. Modulating factors of radical intensity and cytotoxic action of ascorbate. Anticancer Res 1997; 17: 3513.

29. Sakagami H, Satoh K, Hakeda Y, Humagawa M. Apoptosisinducing activity of vitamin C and vitamin K. Cell Mol Biol 2000; 46: 129.

30. Padayatty SJ, Levine M. Reevaluation of ascorbate in cancer treatment emerging evidence, open minds and serendipity. J Am Coll Nutr 2000; 44: 257-64.

31. Takemura Y, Satoh M, Satoh K, Hamada H, Sekido Y, Kubota S. High dose of ascorbic acid induces cell death in mesothelioma cells. Biochem Bioph Res Commun 2010; 394: 249-53.

32. Błasiak J, Gloc E, Woźniak K, et al. Genotoxicity of idarubicin and its modulation by vitamins $C$ and $E$ and amifostine. Chem Biol Interact 2002; 140: 1-18.

33. Błasiak J, Trzeciak A, Gąsiorowska A, Drzewoski J, MałeckaPanas E. Vitamin C and quercetin modulate DNAdamaging effect of N-methyl-N'-nitro-N-nitrosoguanidine (MNNG). Plant Foods for Hum Nutr 2002; 57: 53-61.

34. Woźniak K, Czechowska A, Błasiak J. Cisplatin-evoked DNA fragmentation in normal and cancer cells and its modulation by free radical scavengers and tyrosine kinase inhibitor ST1571. Chem Biol Interact 2004; 147: 309-18. 